\title{
Abietane and pimarane diterpene acid evolution in Scots pine Pinus sylvestris needles in relation to feeding of the pine sawfly, Diprion pini L.
}

\author{
L Buratti $^{1}$, JP Allais ${ }^{1 *}, \mathrm{C} \mathrm{Geri}^{2}, \mathrm{M} \mathrm{Barbier}^{1}$ \\ 1 Institut de Chimie des Substances Naturelles - CNRS 91198 Gif-sur-Yvette, Cedex; \\ 2 Station de Zoologie Forestiere - INRA Ardon 45160 Olivet, France
}

(Received 16 February 1989; accepted 30 June 1989)

\begin{abstract}
Summary - Abietane and pimarane resin acids extracted from the needles of Scots pine, Pinus sylvestris, were analysed by reverse phase HPLC followed by GC of their methyl esters, in relation to the seasons, or the age of the trees. $P$ sylvestris is the habitual host plant of the sawfly Diprion pini (Hymenoptera, Diprionidae) and results of the analyses were correlated with the feeding pattern of this insect in nature. An increase in resin acid concentration was observed during the growing season, but no direct relationship could be established with the feeding preferences of these insects. Young pines contained lower levels of abietane and pimarane diterpene acids than 10 or 30 year-old pines. Previous defoliation induced an increase in the neutral fraction and, although less so, in the diterpene acids in the needles formed the following year. The observed results are discussed in relation to the development of Diprion pini larvae and to previous hypotheses from other authors concerning the antifeedant properties of the resin acids. It is concluded that, if the abietane and pimarane diterpene acids interfere with the biology of Diprion pini, they cannot, however, be considered as the most important factors in the natural equilibria of this species.
\end{abstract}

Pinus sylvestris / Diprion pini / Diprionidae / sawfly / abietane and pimarane diterpene acids / pine foliage / seasonal average variation / antifeedant property

Résumé - Évolution des acides diterpéniques de types abiétique et pimarique dans le feuillage du pin sylvestre pinus sylvestris $L$; impact de l'âge des aiguilies et des arbres, influence des défoliations passées. Conséquences pour le lophyre du pin Diprion pini $\mathrm{L}$. Les acides résiniques de types abiétique et pimarique extraits des aiguilles du pin sylvestre. Pinus sylvestris, ont été analysés par HPLC sur phase inverse et CPG de leurs esters méthyliques, en fonction des saisons et de l'âge des arbres. P sylvestris est la plante hôte habituelle de Diprion pini (Hymenoptères, Diprionidés) et les résultats des analyses ont eté corrélés à l'aptitude de cet insecte à se nourrir sur le feuillage de cet arbre. On note une augmentation du taux des acides résiniques à la belle saison, durant la phase de croissance des aiguilles, mais aucune relation directe n'a pu être observée pour expliquer les preferences alimentaires de cet insecte. Les jeunes pins contiennent un taux plus faible d'acides résiniques de types abiétique et pimarique que les arbres âgés de 10 ou 20 ans. La défoliation

Correspondence and reprints 
de l'arbre induit dans les aiguilles formées l'année suivante une augmentation du taux deslipides neutres et, à moindre titre, des acides résiniques (plus particulièrement de l'acide abiétique). Les résultats obtenus sont discutés en fonction du choix alimentaire des larves de $\mathrm{D}$ pini et des hypothèses émises par d'autres auteurs concernant l'action anti-appetante des acides résiniques. En conclusion, l'aptitude de $\mathrm{D}$ pini à consommer le feuillage du pin sylvestre. Pinus sylvestris, ne parait pas être directement liée aux variations de sa teneur en acides résiniques de types pimarique et abiétique. Toutefois ceci n'exclut pas toute action des ces composés dans la relation D pini - Pinus sylvestris comme le suggèrent certains résultats: taux particulièrement élevé de l'acide abiétique dans le feuillage des pins un an après une défoliation et dans les aiguilles des essences non attaquées tel Pinus pinaster. Seule une étude exhaustive des composés de la fraction acide, et de leur variations nous permettra d'apprecier le rôle effectif des acides résiniques dans les interactions Diprions-Pins sylvestres.

\section{Pinus sylvestris / Pinacée / Diprion pini / Diprionide / Tenthrede / acide pimarique / acide abiétique / aiguille de pin / feuillage / variation salsonnière / propriété anti- appétante}

\section{INTRODUCTION}

Scots pine, Pinus sylvestris L, is an economically important European pulpwood and lumber conifer. Diprion pini L (Hymenoptera, Diprionidae), a widespread pine sawfly living in European coniferous forests, is able to cause serious damage to Scots pines during its outbreaks. Thus, thousands of hectares can be defoliated in less than 2 years (Dusaussoy and Geri, 1966; Eichhorn, 1982; Geri et al, 1982; Geri and Goussard, 1984; Geri, 1988).

$D$ pini does not feed on young, but on mature, foliage, as is the case for many Diprionidae and even other sawfly species (All and Benjamin, 1975a, b; All et al, 1975; Ikeda et al, 1977a, b. Wagner et al, 1979; Niemela et al, 1982). As previously shown, young foliage has a deterrent effect on sawflies and affects larval survival of $D$ pini (Geri et al, 1985, 1988).

Previous results suggested that resin acids could be involved in the deterrence of young foliage. Thus, abietane and pimarane diterpene acids were tested for antifeedant activity against the larvae of various Neodi- prion or Diprion species living on the Jack pine, Pinus banksiana, Lambert (Schuh and Benjamin, 1984a, b); they were also tested on Pristiphora erichsonii, Hartig larvae living on Larix laricinia, Du Roi ( $\mathrm{K} \mathrm{Koch)} \mathrm{(Wagner} \mathrm{et} \mathrm{al,}$ 1983). All these authors concluded that resin acids could be the compounds affecting sawfly larval development.

If abietane and pimarane diterpere acids interfere with larval mortality and feeding behaviour in $D$ pini, the qualitative and quantitative evolutions of these compounds in the foliage should be corielated to the habitual feeding pattern of this insect.

Previous analyses of Pinus sylvestris needle resin acids reported the presence of labdane diterpene acids such as manoyl oxid acid (Bardyshev et al, 1981), pinificolic acid (Enzell and Theander, 1962), dehydropinifolic acid (Norin et al, 1971, 1980), 4-epi-imbricataloic acid (Tobolski and Zinkel, 1982), and of classical pimarane and abietane diterpene acids such as pimaric, isopimaric, sandaracopimaric, abietic, palustric, levopimaric, dehydroabietic and neoabietic acids (Norin, 1972; Tobolski and Zinkel, 1982). 
This paper attempts to correlate the temporal distribution of abietane and pimarane diterpene acids in extracts from Scots pine needles with the ability of $D$ pini to feed on the pine foliage. Abietane and pimarane diterpene acids were selected because they were usually tested in sawfly feeding bioassays (Wagner et al, 1983; Schuh and Benjamin, 1984a, b).

\section{SOME BIOLOGICAL DATA}

In France, Diprion pini chiefly attacks Pinus sylvestris but Pinus nigra Arnold ssp. laricio is also weakly damaged at the end of such outbreaks. $P$ pinaster Aiton is almost never attacked. Exotic species such as $P$ contorta Dougl and $P$ radiata $D$ Don show some damage (Geri, 1988). Diterpene acid analysis was carried out on the mature foliage of these species to find out if the damage could be correlated to pimarane and abietane resin acid rates.

Diprion pini is usually bivoltine in the Paris Basin. The first generation develops from April to July. Eggs are laid as early as mid-April and hatch between late May and early June. The larvae feed on the foliage of the previous years and their growth generally ends at the beginning of July. At this time the larvae disperse and transform to eonymphs, which spin cocoons on vegetation or in the duff, and then change successively into pronymphs, pupae, and adults. Adults emerge from the cocoons at the end of July and give birth to the second generation. Larvae of this second generation develop between late August and October. These larvae feed on previous year as well as current year foliage. Thus as shown by previous bioassays, the new foliage of Scots pine is repellent to $D$ Pini larvae and this repellency decreases with time
(Geri et al, 1985, 1987). Systematic analyses were caried out on selected Scots pine foliage during a period ranging from June to September.

$D$ pini lives preferably on old trees, the young pines being attacked only during outbreaks (Geri and Goussard, 1984; Geri, 1988). The same phenomenon was observed in Sweden on Scots pine defoliated by Neodiprion sertifer, Geoff. (Larsson and Tenow, 1984). As a consequence of these previous observations, analyses were also carried out on the foliage of trees of different ages.

Furthermore, long lasting resistance induced by defoliation (Haukioja and Hakala, 1975; Haukioja, 1980) could play a crucial role in the collapse of leaf feeder populations. For example, needle quality of Larix decidua remained low for defoliators 4 years after defoliation, inducing a decrease in the success of the insect Zeiraphera diniana Guenée (Benz, 1974; Baltensweiler et al, 1977; Fischlin and Baltensweiler, 1979). Quantitative resin acid changes were shown to occur after wounds in Pinus sylvestris bark (Gref and Ericsson, 1984). We found that the development of $D$ pini larvae feeding on new foliage of pines defoliated the previous year was altered. We observed in particular a significant decrease in female fecondity (Geri et al, 1988). Newly formed Scots pine needles from trees defoliated either artificially in the previous Spring or by Diprion pini in the previous Summer, were also extracted and analysed.

\section{MATERIALS AND METHODS}

Current year needle samples were collected in 1984 on June 27th, July 16th, August 1st, 14th and September 10th on several twigs 
of the same $5 \mathrm{ca}$. 10 year-old pines from a pine plantation at Olivet, INRA Forest Laboratory, near Orléans (France). This plantation is an homogenous plantation growing from wild seeds (the most likely origin being from Hagueneau forest). All the trees of this plantation were normally attacked by Diprions during the last outbreak but were free of sawflies for at least three years. Their foliage was used for feeding and breeding experiments which have been reported in other papers (Geri, 1986; Geri et al, 1988). On May 22th, 1984, samples of foliage formed in 1982 and 1983 were also collected.

The role of tree age was studied using 5,10 and 30 year-old pines (from the Olivet plantation for the first 2 and from the Orleans forest for the latter) from which one year-old needles were collected on May 28th and June 6 th, 1984. The defoliation effect was investigated on 10 year-old pines (Olivet pine plantation) which were partly defoliated by man during the spring of 1983 or by $D$ pini larvae during the Summer of 1983. The current year foliage from artificially defoliated pine was collected on July 19th, 1984 and from the naturally defoliated pine on September 10th, 1984.

The collected needles were frozen and kept at $-20^{\circ} \mathrm{C}$ until extraction and analysis. Fifty $g$ (fresh weight) of each sample were ground using a Waring Blendor and extracted 3 times with methanol/dichloromethane $1 / 1(\mathrm{v} / \mathrm{v})$. The solutions were filtered through a glass fritted filter and the crude extracts were dried in a Bûchi rotavapor at ambient temperature. The needle dry weight $(d w)$ is the sum of the crude extract and extracted needle dry weights.

The crude extract was fractionated into acid and neutral fractions by agitation with $2 \% \mathrm{NaOH}$, followed by dichloromethane extraction. After the neutral organic phase elimination, the $\mathrm{NaOH}$ aqueous phase was acidified with $1.2 \mathrm{~N} \mathrm{HCl}$ and the acids extracted with dichloromethane.

The acid fraction was chromatographed by reverse phase HPLC (Perkin Elmer 2A pump with LC 75 UV-Visible detector at $241 \mathrm{~mm}$ ) on a Whatman Partisil M9 10-50 C8 column $(500 \times 9.4 \mathrm{~nm})$. The elution mixture was methanol/water/isopropanol/orthophosphoric acid $350 / 150 / 50 / 0,1(\mathrm{v} / \mathrm{v})$ at $3 \mathrm{ml} / \mathrm{mn}$. The pimarane and abietane diterpene acids flowed out together after $50 \mathrm{~min}$.
The resin acids were converted by diazomethane to the corresponding methyl esters and analysed by Gas Chromatography (Varian series 1400 , Flame Ionisation Detector) on an Alltech RSL 150 Megabore column (15 $\mathrm{m} \times 0.53 \mathrm{~mm})$. The oven temperature was programmed between 120 ${ }^{\circ} \mathrm{C}$ and $180^{\circ} \mathrm{C}$ at $6{ }^{\circ} \mathrm{C} / \mathrm{mn}$, from $180^{\circ} \mathrm{C}$ to $195^{\circ} \mathrm{C}$ at $1^{\circ} \mathrm{C} / \mathrm{mn}$ and from $195^{\circ} \mathrm{C}$ to 255 ${ }^{\circ} \mathrm{C}$ at $2{ }^{\circ} \mathrm{C} / \mathrm{mn}$. Individual resin acids were identified by direct comparison and cochromatography with authentic samples (Helix Biotech. Ltd, Vancouver, Canada) and by ${ }^{1} \mathrm{H}$ $\mathrm{NMR}$ after $\mathrm{NO}_{3} \mathrm{Ag}$ TLC isolation. Absolute amounts of resin acids were estimated by peak area triangulation, compared with resin acid standard solutions and corrected by reference to an internal standard of methylpalmitate. The reported data are the averages of at least 3 different determinations carried out on the same material.

\section{RESULTS}

Lipids, acid fractions, abietane and pimarane diterpene acid rates in Scots pine foliage in relation to the needle age, are listed in table I. Lipids increase in the current year foliage during the growing season (from $2.45 \%$ to $7.1 \% \mathrm{dw}$ ). The acid fraction containing the pimarane and abietane resin acids follows a parallel evolution from $0.84 \%$ to $2.03 \%$ (dw). These acids are principally represented by pimarane acids (mainly sandaracopimaric acid) while the abietane acids (except for the $08 / 01 / 84$ sample) represent only $25 \%-$ $50 \%$ of their rates. The total level of these acids increases from early Spring to late Summer (from $0.030 \%$ to $0.130 \% \mathrm{dw}$ ). However, the different groups do not show the same evolution: pimarane resin acids gradually increase during the growing season in contrast to abietane resin acids which maintain the same level throughout (except in August, which had a higher value). We did not manage to detect 
Table I. Evolution of abietane and pimarane resin acids in the foliage of Pinus sylvestris in relation to Diprion pini feeding ability.

${ }^{*}: \mathrm{g}^{\mathrm{kg}}{ }^{\prime}(\mathrm{dw}){ }^{* \star}: \mathrm{mg}^{\mathrm{kg}}{ }^{\prime}(\mathrm{dw}) ;+$ : foliage sampled during a period of good $D$ pini feeding ability; -: foliage sampled during a period of poor $D$ pini feeding ability

\begin{tabular}{|c|c|c|c|c|c|c|c|}
\hline $\begin{array}{l}\text { Foliage ability } \\
\text { to } D \text { pini feeding }\end{array}$ & + & + & - & - & + & + & + \\
\hline Foliage year & 1982 & 1983 & 1984 & 1984 & 1984 & 1984 & 1984 \\
\hline Sampling dates & $5 / 22 / 84$ & $5 / 22 / 84$ & $6 / 27 / 84$ & $7 / 16 / 84$ & $8 / 01 / 84$ & $8 / 14 / 84$ & $9 / 10 / 84$ \\
\hline Water (\% fresh weight) & 6.5 & 23.3 & 28.7 & 30.7 & 55.5 & 41.4 & 51.9 \\
\hline Total lipids $\left(^{*}\right)$ & 136.0 & 38.9 & 24.7 & 32.4 & 53.5 & 53.4 & 71.0 \\
\hline Acid fraction $\left({ }^{*}\right)$ & 7.64 & 7.82 & 8.42 & 10.76 & 18.74 & 16.53 & 20.35 \\
\hline $\begin{array}{l}\text { Abietane + pimarane: } \\
\text { acids }\left({ }^{* *}\right)\end{array}$ & 11.62 & 20.08 & 27.31 & 28.99 & 178.66 & 79.01 & 133.04 \\
\hline Pimaric acid $\left({ }^{\star *}\right)$ & 0.34 & 1.17 & 2.19 & 1.38 & 4.04 & 7.20 & 30.67 \\
\hline sandaracopimaric acid $\left({ }^{* *}\right)$ & 7.08 & 12.55 & 12.74 & 19.24 & 43.41 & 40.91 & 46.94 \\
\hline $\begin{array}{l}\text { Isopimaric acid }\left({ }^{* *}\right) \\
\text { Palustric + }\end{array}$ & 0.90 & 2.45 & 3.31 & 2.54 & 9.71 & 12.87 & 26.38 \\
\hline levopimaric acids & $\operatorname{tr}$ & $\operatorname{tr}$ & $\operatorname{tr}$ & $\operatorname{tr}$ & $\operatorname{tr}$ & $\operatorname{tr}$ & $\operatorname{tr}$ \\
\hline Dehydroabietic acid ("*) & 1.31 & 2.45 & 5.42 & 3.40 & 54.73 & 8.47 & 17.15 \\
\hline Abietic acid $(* \pi)$ & 0.28 & 0.34 & 0.73 & 0.81 & 29.88 & 4.92 & 2.95 \\
\hline Neoabietic acid $\left(^{\star \star}\right)$ & 1.71 & 1.12 & 2.92 & 1.62 & $36 . .89$ & 4.64 & 8.95 \\
\hline
\end{tabular}

any trace of levopimaric, or palustric acids. In early Spring, 1 or 2 year-old foliage, as well as current year foliage, contained similar amounts of resin acids (between $0.012 \%$ and $0.03 \%$ $d w)$.

There is no obvious connection between a low rate of pimarane and abietane diterpene acids and the ability of $D$ pini to feed on pine foliage as shown by observations in nature or with laboratory experiments as summarised in table I (these observations were reported in other papers - Geri et al, 1986, 1987). In Spring these diterpene acid rates are low both in the previous year foliage which is not antifeedant and in the new foliage which is antifeedant, while they are high in late Summer and Autumn in the current year foliage which can be consumed by the Diprions. Nevertheless, in the 1 or 2 year-old pine foliage, these rates are particularly low with regard to the total lipid fraction.
The abietane and pimarane diterpene acid contents determined in the extracts of 5,10 , and 30 year old pine foliage are reported in table II. Old pines (10 and 30 year-old) contain higher levels of diterpene acids in their foliage and an evolution occurs with time, the pimarane resin acids being more abundant in 10 year-old specimens and abietane resin acids becoming more abundant in old pines. The oldest Scots pine are more easily attacked by Diprions than the youngest, so that the feeding ability appears to be correlated with a high level of diterpene resin acids. Such preferences for older trees were noticed by Geri and Goussard (1984) for $P$ sylvestris and also observed for pines attacked by Neodiprion sertifer Geoffr in Southern and Central Sweden (Larson and Tenow, 1984).

The abietane and pimarane diterpene acid rates determined in the new foliage of $P$ sylvestris after a previous 
Table II. Evolution of abietane and pimarane resin acids in the foliage of Pinus sy/vestris in relation to tree age.

${ }^{*}: \mathrm{g} \cdot \mathrm{kg}^{-1}(\mathrm{dw}) ;{ }^{* *}: \mathrm{mg} \cdot \mathrm{kg}^{-1}(\mathrm{dw})$

\begin{tabular}{lccc}
\multicolumn{1}{c}{ Tree age } & 5 years & 10 years & 30 years \\
Foliage year & 1983 & 1983 & 1983 \\
Sampling dates & $5 / 25 / 84$ & $5 / 25 / 84$ & $6 / 07 / 84$ \\
Water (\% dw) & 48.3 & 40.3 & 47.3 \\
Total lipids $\left(^{\star}\right)$ & 127.7 & 221.0 & 106.4 \\
Acid fraction $\left(^{*}\right)$ & 6.7 & 28.5 & 11.5 \\
Abietane + Pimarane acids $\left(^{* *}\right)$ & 26.8 & 36.9 & 41.5 \\
Pimaric acid $\left(^{* *}\right)$ & 1.0 & 2.0 & 1.3 \\
Sandaracopimaric acid $\left(^{* *}\right)$ & 13.0 & 24.8 & 14.4 \\
Isopimaric acid $\left(^{* *}\right)$ & 2.5 & 2.0 & 2.1 \\
Palustric + levopimaric acids & $\mathrm{tr}$ & $\mathrm{tr}$ & $\mathrm{tr}$ \\
Dehydroabietic acid $\left(^{* *}\right)$ & 3.8 & 3.7 & 1.6 \\
Abietic acid $\left(^{* \star}\right)$ & 3.3 & 1.2 & 18.4 \\
Neoabietic acid $\left(^{* *}\right.$ & 3.2 & 3.2 & 3.7 \\
\hline
\end{tabular}

defoliation are listed in table III. These results show an increase in the total lipids compared with normal foliage. In fact, this phenomenon is due to a high increase in the neutral lipids which doubled (from $2.18 \%$ to $5.14 \%$ and from $5.07 \%$ to $10.93 \%$ dw for the July and September samples respectively). Nevertheless, the average of abietane and pimarane diterpene acids relative to the needle dry weight is also about twice as high in previously defoliated new foliage collected in July and September than in undefoliated pine

Table III. Evolution of abietane and pimarane resin acids in the new foliage of Pinus sylvestris after previous defoliation.

*: g. $\mathrm{kg}^{-1}(\mathrm{dw}) ;{ }^{* *}: \mathrm{mg} \cdot \mathrm{kg}^{-1}(\mathrm{dw})$

\begin{tabular}{|c|c|c|c|c|}
\hline & $\begin{array}{c}\text { No } \\
\text { defoliation }\end{array}$ & $\begin{array}{c}\text { Tree } \\
\text { artificially } \\
\text { defoliated }\end{array}$ & $\begin{array}{c}\text { No } \\
\text { defoliation }\end{array}$ & $\begin{array}{c}\text { Tree } \\
\text { naturally } \\
\text { defoliated }\end{array}$ \\
\hline Defoliation period & & 1983 Spring & & $\begin{array}{l}1983 \text { Sum- } \\
\text { mer }\end{array}$ \\
\hline Foliage year analysed & 1984 & 1984 & 1984 & 1984 \\
\hline Sampling dates & $7 / 16 / 84$ & $7 / 19 / 84$ & $9 / 10 / 84$ & $9 / 10 / 84$ \\
\hline Water ( $\%$ fresh weight) & 30.7 & 56.3 & 51.9 & 49.2 \\
\hline Total lipids $\left(^{*}\right)$ & 32.4 & 66.5 & 71.0 & 121.1 \\
\hline Abietane + Pimarane & 10.76 & 10.97 & 20.35 & 11.81 \\
\hline acids $\left({ }^{* \star}\right)$ & 28.99 & 66.29 & 133.04 & 223.18 \\
\hline Pimaric acid $\left({ }^{\star \star}\right)$ & 1.38 & 5.30 & 30.67 & 2.56 \\
\hline Sandaracopimaric acid $(* *)$ & 19.24 & 37.03 & 46.94 & 31.06 \\
\hline Isopimaric acid $\left({ }^{\star *}\right)$ & 2.54 & 6.31 & 26.38 & 9.25 \\
\hline Palustric+levopimaric acids $(* *)$ & $\operatorname{tr}$ & 1.83 & tr & 8.98 \\
\hline Dehydroabietic acid $\left({ }^{* \star}\right)$ & 3.40 & 5.07 & 17.15 & 15.94 \\
\hline Abietic acid $\left({ }^{* *}\right)$ & 0.81 & 8.14 & 2.95 & 60.35 \\
\hline Neoabietic acid $\left.{ }^{* *}\right)$ & 1.62 & 2.61 & 8.95 & 95.04 \\
\hline
\end{tabular}


needles from the same periods. This increase seems to be mainly due to abietic and neobietic acids while pimarane diterpene acids decreased slightly in the September experiment. Levopimaric and palustric acids were also observed in these lipid fractions as shown in table III.

Abietane and pimarane diterpene acid rates of the main French pine species on which $D$ pini can develop more or less easily are given in table IV. The ability of this insect to live on a particular pine species is hard to correlate with the presence (or absence) of any characteristic resin acid. All species have about the same acid fraction level, namely 0.05 to $0.12 \%$ of foliage dw. However, Scots pine foliage contains less abietane and pimarane diterpene acids than other species $(20 \mathrm{ppm}$ reported for $P$ sylvestris, 112 ppm for $P$ pinaster and 42,47 , and 55 ppm for $P$ radiata, $P$ contorta and $P$ laricio respectively). Moreover, we observed that the Scots pine abietane resin acid level is particularly low (3.8 ppm) compared with the observed rates in the other species (73.5 in $P$ pinaster for example).

\section{DISCUSSION}

The acid fraction level $(0.76 \%$ to $2.03 \%$ $d w)$ found in Scots pine needles is about the same as that found by Enzell and Theander, $1962,(0,043 \% \mathrm{dw})$, or by Norin et al, 1971, (1,86\% dw). However, pimarane and abietane diterpene acids represent only a small part of this fraction (about $0.1 \%$ to $1 \%$ of these acids).

Tobolski and Zinkel, 1982, found a higher resin acid rate which evolved from $33.4 \mathrm{mg} / \mathrm{g}$ to $45.7 \mathrm{mg} / \mathrm{g}$ dw (namely $3.3 \%$ to $4.57 \% \mathrm{dw}$ ) in the extracts of Scots pine needles. In their studies, pimarane and abietane diterpene acids represented from 13\%-40\% of the total resin acids. Thus they, reported values which are 10-40 times higher than our data. It is difficult to understand the difference between pre-

Table IV. Comparisons of abietane and pimarane diterpene acid levels in the foliage of various pine species, in relation to Diprion pini attacks.

«: $g \cdot \mathrm{kg}^{-1}(\mathrm{dw}){ }^{\star \star}: \mathrm{mg} \cdot \mathrm{kg}^{-1}(\mathrm{dw}) ;(+++)$ : habitual host plant; $(++)$ : substitution host plant; $(+)$ : exceptional host plant; (0): no perceptible attack

\begin{tabular}{|c|c|c|c|c|c|}
\hline Pine species & P sylvestris & $P$ contorta & $P$ laricio & $P$ radiata & $P$ pinaster \\
\hline Attack of Diprions & +++ & + & + & + & 0 \\
\hline Foliage year & 1983 & 1983 & 1983 & 1983 & 1983 \\
\hline Sample dates & $5 / 22 / 84$ & $5 / 22 / 84$ & $5 / 22 / 84$ & $5 / 22 / 84$ & $5 / 22 / 84$ \\
\hline Water ( $\%$ fresh weight) & 23.3 & 35.5 & 59.8 & 35.4 & 60.3 \\
\hline Total lipids $\left(^{*}\right)$ & 38.9 & 169.9 & 109.9 & 44.9 & 109.5 \\
\hline Acid fraction $\left(^{*}\right)$ & 7.82 & 10.36 & 12.48 & 4.64 & 9.66 \\
\hline Abietane +pimarane acids $\left({ }^{* *}\right)$ & 20.08 & 46.84 & 54.67 & 42.11 & 111.83 \\
\hline Pimaric acid $\left({ }^{* *}\right)$ & 1.17 & 0.23 & 3.55 & 0. & 8.26 \\
\hline Sandaracopimaric acid $\left({ }^{* \star}\right)$ & 12.55 & 0.47 & 20.28 & 4.33 & 26.60 \\
\hline Isopimaric acid $\left({ }^{\star \star}\right)$ & 2.45 & 0.99 & 2.83 & 0.84 & 3.56 \\
\hline Palustric+levopimaric acids $\left({ }^{\star \star}\right)$ & $\operatorname{tr}$ & 1.64 & $\operatorname{tr}$ & 1.52 & 3.10 \\
\hline Dehydroabietic acid (**) & 2.45 & 1.18 & 2.46 & 14.15 & 3.93 \\
\hline Abietic acid $\left({ }^{\star *}\right)$ & 0.34 & 41.15 & 23.56 & 12.85 & 64.57 \\
\hline Neoabietic acid $\left(^{* *}\right)$ & 1.12 & 1.18 & 1.99 & 8.42 & 1.81 \\
\hline
\end{tabular}


vious observations and the present results. One could, perhaps, explain these discrepancies by genetic divergences between North American, North European and Central European species. Larsson et al, 1984, stated that the resin acid rates could be characteristic of some clones; they reported the existence of clones with high levels of resin acids $(5.2 \% \mathrm{dw})$ and of others poorer in resin acids $(1.52 \% \mathrm{dw})$. The first contained twice as much abietic, levopimaric, and palustric acids than the latter, but, unfortunately, these authors did not give any data on the levels of pimarane diterpene acids. Climatic factors such as humidity, temperature, or sunlight are not negligible; indeed, recently, Gref and Tenow, 1987, reported that needies from sunny sites contained more resin acids than needles from the shade $(2.24 \% \mathrm{dw}$ for the first and $1.37 \% \mathrm{dw}$ for the second); in this study as in that of the previous authors, the level of pimarane diterpene acids is not mentioned.

Moreover, all these authors worked on an acidic fraction which contained compounds such as labdane diterpene acids and their oxidised derivatives in addition to the pimarane and abietane diterpene acids. We have shown that pimarane and abietane resin acids represent only a small part of the total acid fraction, mainly composed of labdanic acids and of hydroxylated derivatives of diterpene acids (Buratti et al, 1987). in our study, the isolation of the total acids by HPLC allows us to obtain abietane and pimarane diterpene acids together; the more polar hydroxylated diterpene acids such as the labdane diterpene acids, are separated by the same chromatography.

Other data concerning $P$ sylvestris result from pine seedling bark analyses - between $0.8 \%$ and $3 \% \mathrm{dw}$ - (Gref and Ericson, 1984), or wood analyses - about $0.74 \% \mathrm{dw}$ - (Yildrim and Holmbon, 1977). These results cannot be compared with our data since we have only analysed the needles. Like Greff and Ericsson, 1984 and Gref and Tenow, 1987, we observed an increase of pimarane and abietane diterpene acids during the growing season while Tobolski and Zinkel, 1982 found an opposite pattern.

In studies on the predominant role of resin acids in the control of sawfly populations, different authors (Ohigashi et al, 1981; Wagner et al, 1983; Shuh and Benjamin, 1984a, b) reported that abietane and pimarane resin acids added to mature foliage inhibited larval feeding and growth. They concluded that these resin acids may contribute significantly to the natural deterrence of the current season foliage against Diprions. Their conclusions are drawn from experimental results and a previous observation by Ikeda et al, 1977, who found in $P$ banksiana foliage a diterpene acid (13-keto 8(14)-podocarpene 18-oic acid) which deterred larval feeding of $N$ rugifrons and $N$ swanei. This compound occurred at high levels in Spring in the new foliage and decreased throughout the growing season.

With $D$ pini, the nutritional experiments that we made, gave doubtful results (Geri et al, 1985). In addition we found an increase of the amount of 13keto 8(14)-podocarpene 18-oic acid in the $P$ sylvestris foliage during the growing season (Buratti et al, 1988). Now, we have shown that the pimarane and abietane diterpene acids increase from early Spring to Autumn. That is to say that the increase of the supposed deterrents correspond with the feeding season of $D$ pini larvae - a rather contradictory statement. After these obser- 
vations it is difficult to conclude that these acids have a determinant role in the choice of foliage during Diprion attacks. If such a relationship existed, it would be advisable to observe the correlation between high levels of these compounds in the pine needles and the incapacity of $D$ pini to live on them.

We observed that $D$ pini reared on Scots pine, defoliated the previous year, developed more quickly resulting in less weight gain and reduced fecundity (Geri et al, 1988). Niemela et al 1984, reported that Neodiprion sertifer developed more quickly on pines which were partly defoliated the previous Summer while Microdiprion pallipes showed a higher mortality. There is no doubt that defoliation can have an influence on the defoliators which develop on the pines the following year. Most certainly, if the factors which interfere with the development of Diprions are contained in the lipid fraction extracted from the needles, the inducing factors should be looked for in the neutral fraction (which increases from $2.18 \%$ to $5.14 \% \mathrm{dw}$ in July and from 5.12 to $10.9 \% \mathrm{dw}$ in September) rather than in the acid fraction. Nevertheless, the average of abietane diterpene acids increased greatly after defoliation when the pimarane diterpene acids either remained at about the same level or decreased.

It is not possible to correlate resin acid levels and the importance of $D$ pini attacks on the different pine species, especially if we consider (table 1) that resin acid levels in Scots pine foliage reached their highest value in late Summer, when it is actively consumed by Diprions. However, $P$ sylvestris, the pine which is most often attacked by Diprions, contains the lowest level of abietane diterpene acids and $P$ pinaster, the most rarely at- tacked pine contains the highest rate of abietane diterpene acids.

From all these results, we can conclude that, if the abietane and pimarane diterpene acids of Scots pine needles can interfere in the $D$ pini development, they probably cannot be considered as determinant factors for the natural equilibria of this species. It is noticeable however that pimarane diterpene acids increase regularly during the growing season, an evolution which is modified little by previous defoliations while the amount of abietane diterpene acids is greatly modified by defoliations.

\section{REFERENCES}

All JN, Benjamin DM (1975a) Deterrents in Jack pine, Pinus banksiana, influencing larval feeding behaviour and survival of Neodiprion swainei and $N$ rugifrons. Ann Entomol Soc Am 68, 495-499

All JN, Benjamin DM (1975b) Influence of the needle maturity on larval feeding preference and survival of Neodiprion swaine and $N$ rugifrons on Jack pine, Pinus banksiana. Ann Entomol Soc Am 68, 579584

All JN, Benjamin M, Matsumara $F$ (1975) influence of semi purified constitutents of juvenils Jack pine. Pinus banksiana, foliage and other pine-derived chemicals on feeding of Neodiprion swainei and $N$ rugifrons larvae. Ann Entom Soc Am 68, 1095-1 101

Bardyshev II, Degtiarenko AS, Pertsovskii AL, Kruik SI (1981) The chemical composition of higher fatty and resin acids contained in the needles of Pinus sylvestris. Khim Drev 3, 102-104

Baltensweiler W, Benz G, Bouey P, Delucchi $V$ (1977) Dynamics of larch bud moth populations. Ann Rev Ent 22, 79-100

Benz G (1974) Negative Ruckkoppelung durch Raum und Nahrungskonkurrenz sowie zyklische Veränderungen der Nahrungsgrunlage als Regelprinzip in der Populations dynamik des Grauen Lar- 
chenswicklers, Zeiraphera diniana Guenée (Lepidoptera, Torttricidae). Z Ang Ent 76, 196-228

Bridgen MR, Hanover JW (1982) Indirect selection for pest resistance using terpenoid compounds. In: Resistance to diseases and pest in forest trees (Heybroek $H M$, Stephan BR, Von Weissenberg $K$, eds) Wageningen, 161-168

Buratti L, Allais JP, Barbier M (1988) The resin acid involved in the relation between Scots pine and the sawfly Diprion pini L. - The contents of diterpene resin acids in the needles. 171-187. In: Mechanisms of woody defenses against insects - (Mattson, Levieux, Bernard-Dagan, ed). Springer Verlag. New-York, 171-187

Dusaussoy G, Geri C (1966) Etude d'une population de Diprion pini (Hymenoptères, Symphytes) en forẻt de Fontainebleau. 1 - Données biologique sur Diprion pini et sur les principaux parasites. Ann Soc Ent F 2, 503-534

Dusaussoy G, Geri C (1971) Étude des populations résiduelles de Diprion pini $\mathrm{L}$ à Fontainebleau après la gradation de 1963-1964. Ann Sci Forest 28, 297-322

Eichhorn VO (1982) Studies on the ecology of the common pine sawfly Diprion pini. VII - factors infiuencing the population dynamics. $Z$ Ang Ent 94, 271-300

Enzell C. Theander $O$ (1962) The constituents of conifer needles. II/ Pinifolic acid, a new diterpene acid isolated from Pinus sylvestris. Acta Chem Scand 16, 607-614

Fischlin A, Baltensweiler W (1979) System analysis of the larch bud moth system. Part 1: The larch-larch budmoth relationship. Mitt Schweiz Ent Ges 52, 273-289

Geri C (1986) Facteurs influençant la dynamique des populations de Diprion pini L. dans le Bassin Parisien. 18th IUFRO Congress. Lubjana. Proceeding division 2 (2), 377-405

Geri C (1988) The pine sawfly in Central France. 377-405 $\mathrm{ln}$ : Forest insects population dynamics (Berryman, ed), Plenum, New York, 377-405

Geri C, Allais JP, Goussard F, Liger A, Yart A (1985) Incidence de l'áge du feuillage sur le développement de Diprion pini $\mathrm{L}$ (Hyménoptères, Diprionidae). Conséquences pour l'évolution des populations. Acta Oecologica/Oecol appl 6, 349-365
Geri C, Buratti L, Allais JP (1988) The resin acids involved in the relation between Scots pine and the sawtly Diprion pini $\mathrm{L}$ II - Correlations with the biology of Diprion pini L. In: Mechanisms of woody plant defenses against Insects (Mattson, Levieux, Bernard-Dagan ed), Springer Verlag, New York, 189-201

Geri C, Goussard F (1984) Evolution d'une nouvelle gradation de lophyre du pin ( $D i$ prion pini) dans le sud du bassin parisien. 1/ Développement de la gradation jusqu'en 1982 et relation avec les facteurs du milieu. Ann Sci For 41, 375404

Geri C. Goussard F, Rousseau G (1982) Situation actuelle des attaques de lophyre du pin (Diprion pini) dans la région centre et en lle de France. La Forêt privée $n^{\circ} 144$

Gref R, Ericsson A (1984) Wound induced changes of resin acid concentrations in living bark of Scots pine seedlings. Can $J$ For Res 17, 346-349

Gref $R$, Tenow $O$ (1987) Resin acids in sun and shade needles of Scots pine (Pinus sylvestris L) Can J For Res 17, 346-349

Haukioja $E$ (1980) On the role of plant defences in the fluctuation of herbivore populations. Oikos 35, 202-213

Haukioja E, Hakala T (1975) Herbivore cycles and periodic outbreaks. Formulation of a general hypothesis. Rep Kevo Subartic Res Stat 12, 1-9

Ikeda T, Matsumura F, Benjamin DM (1977a) Chemical basis for feeding adaptation of pine sawflies Neodiprion rugifrons and Neodiprion swainei. Science 197, $497-$ 499

Ikeda T, Matsumara F, Benjamin DM (1977b) Mechanism of feeding discrimination between matured and juvenile foliage by 2 species of pine sawflies. J Chem Ecol 3 , 677-694

Larsson. S, Bjorkman C, Gref R (1984) Responses of Neodiprion sertifer (Hym. Diprionidae) larvae to variation in needles resin acids concentration in Scots pine. Oecologia (Berlin) 70, 77-84

Larsson S, Tenow O (1984) Areal distribution of Neodirion sertifer (Hym. Diprionidae) outbreak on Scots pine as related to stand condition. Holoarctic Ecology 7. 81-90 
Niemela P, Mannila R, Mantsala P (1982) Deterrent in Scots pine. Pinus sylvestris influencing feeding behavior of the larvae of Neodiprion sertifer (Hymenoptera, Diprionidae). Ann Ent Fenn 48, 57-58

Niemela $P$, Tuomi J, Mannila $R$, Ojala $P$ (1984) The effect of previous damage on the quality of Scots pine foliage as food for diprionid sawflies. $Z$ Ang Ent 98, 3343

Norin T (1972) Review article: Some aspects of the chemistry of the order pinales. Phytochem 11, $1231-1242$

Norin T, Sundin S, Theander O (1971) The constituents of conifer needles 4/ Dehydropinifolic acid, a diterpene acid from the needles of Pinus sylvestris L. Acta Chem Scand 25, 607-610

Norin T, Sundin S, Theander O (1980) The constituents of conifer needles. $7 /$ The configuration of dehydropinifolic acid, a diterpene acid from the needles of Pinus sylvestris L. Acta Chem Scand B34, 301302

Ohigashi $H$, Wagner MR, Matsumara F, Benjamin DM (1981) Chemical basis for differential feeding behaviour of the larch sawfly Pristiphora erichsonii Hartig. J Chem Ecol 7, 599-614

Schun BA, Benjamin DM (1984a) The chemical feeding ecology of Neodiprion dubiosus Schedl., $N$ rugifrons Middl and $N$ lecontei Fitch on Jack pine (Pinus banksiana Lamb). J Chem Ecol 10, $1071-1$ 079
Schuh BA, Benjamin DM (1984b) Evaluation of commercial resin acids as feeding deterrents against Neodiprion dubiosus, $N$ lecontei, $N$ rugifrons (Hymenoptera, Diprionidae). J Economic Ent 77, 802805

Tobolski JJ, Zinkel DF (1982) Variation in needle and cortex resin acids during shoot development in Pinus sylvestris, $P$ nigra, and $P$ strobus. Forest Sci 28, 785796

Wagner MR (1986) Influence of moisture stress and induced resistance in Ponderosa pine Pinus ponderosa Dougl. ex Laws on the pine sawfly Nediprion fulviceps Cresson, complex. For Ecol Manag 15, 43-53

Wagner MR, Benjamin DM, Clancy KM, Schuh BA (1983) Influence of diterpene resin acids on feeding and growth of larch sawfly, Pristiphora erichsonii (Hartig). J Chem Ecol 9, 119-127

Wagner MR, Ikeda T, Benjamin DM, Matsumura F (1979) Host derived chemicals: the basis for preferential behaviour of larch sawfly, Pristiphora erichsonii (Hym Tenthredinidae), on Tamarack, Larix laricinia. Can Ent 111, 165-169

Yildirim $H$, Holbom B (1977) Investigations on the wood extractives of pine species from Turkey. II - Composition of fatty and resin acids in Pinus sylvestris and $P$ nigra. Acta Acad Aboensis B 37, 1-6 